\title{
Amor y matemáticas: El corazón de la realidad oculta
}

\author{
Love and Math: The Heart of Hidden Reality
}

Martín Ortiz-Domínguez ${ }^{a}$

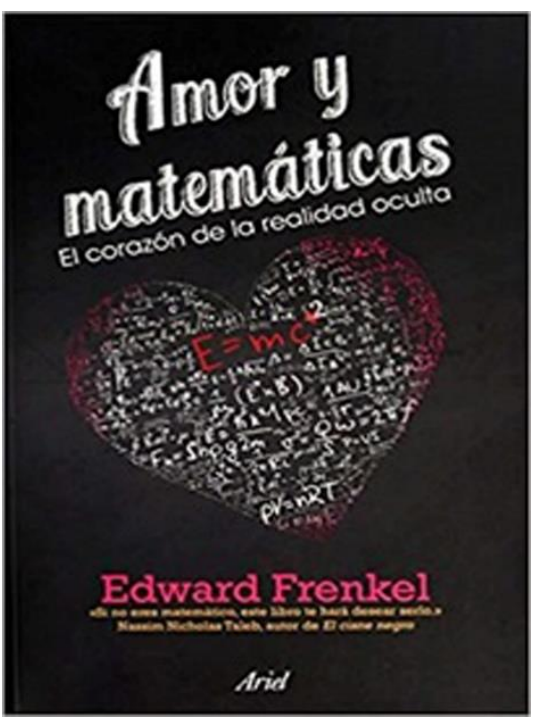

Cualquier persona que quiera dedicarse a la ciencia debe tener ciertos rasgos de personalidad innatos como: creatividad, actitud inquisitiva, inconformidad con labores rutinarias, capacidad de razonamiento abstracto, ambición por logros intelectuales, curiosidad por la naturaleza, pasión por entender el cómo y el porqué de las cosas, etc. Ciertamente, es muy común que las personas con estas cualidades vean el mundo de una forma distinta al común de la gente. En este fascinante libro, uno de los matemáticos más brillantes e importantes de los últimos tiempos nos revela el lado de las matemáticas que jamás hemos explorado, barnizadas con toda la belleza y elegancia de una pieza de arte. El autor nos sumerge en una disciplina presente en el corazón de toda materia, que une culturas, tiempo y espacio. Y lo hace a través de dos historias, la de la evolución y los grandes hallazgos de las matemáticas, y, de forma paralela, la de su biografía personal, que le llevó de ser rechazado en la facultad de matemáticas de Moscú a convertirse en uno de los matemáticos más importantes del siglo XXI. Pero el libro no es sólo una apasionante historia de superación personal teñida de divulgación científica, sino que nos introduce en una nueva forma de pensamiento capaz de enriquecer nuestra vida personal y ayudarnos a entender mejor el mundo y el lugar que ocupamos en él. Es una invitación a descubrir la magia del universo escondido de las matemáticas.

\section{Referencia}

Frenkel, E. (2016). Amor y matemáticas: El corazón de la realidad oculta. México: Ariel. 